\title{
MANGANESE FRACTIONATION ANALYSIS IN SPECIFIC SOIL AND SEDIMENT SAMPLES
}

\author{
GABRIELA NÁDASKÁ, KRISTÍNA POLČOVÁ, JURAJ LESNÝ \\ Department of Biotechnology, University of SS Cyril and Methodius, J. Herdu 2, \\ Trnava, SK-917 01, Slovak Republic (pisarcig@ucm.sk)
}

\begin{abstract}
Manganese has been determined in soil- and sediment samples taken from selected regions with high manganese concentrations anthropogenic and/or geogenic. The total content of manganese in chosen sediment- and soil samples has been determined applying FAAS after microwave digestion and the manganese fractions after sequential extraction procedures using galvanostatic stripping chronopotentiometry. The highest content of manganese has been determined in sediment from Hôrka $\left(6243.6 \pm 56.2 \mathrm{mg} \mathrm{kg}^{-1}\right)$, while the lowest value has been obtained in the sediment from Králová $(278.6 \pm$ $\left.3.9 \mathrm{mg} \mathrm{kg}^{-1}\right)$. Using a modified Tessier's procedure it was found, that manganese in sediments from Král'ová is associated mainly with the carbonate fraction $(>50 \%)$, while in sediments from Lozorno and Hôrka it is associated primarily with the $\mathrm{Mn}$ and Fe oxide fraction ( $80 \%$ and $42 \%$ respectively).
\end{abstract}

Key words: manganese, galvanostatic stripping chronopotentiometry, fractionation analysis

\section{Introduction}

Manganese is an essential micronutrient for all organisms, playing an important role in tissue and bone formation, in reproductive functions and in carbohydrate and lipid metabolisms (ANJOS et al., 2007), but at higher levels it can be toxic. In man, chronic manganese poisoning affects the central nervous system, with symptoms resembling those of Parkinson's disease. Manganese toxicity is a serious constraint to crop cultivation since manganese is taken-up by plants and can easily be passed into the food chain (KHOO et al., 1996; BANKS et al., 2005; PEARSON and GREENWAY, 2005). Therefore, the determination of manganese in several matrices samples is very important for some areas, such as environmental chemistry and food control (LEMOS et al., 2008).

Measurement of total metal concentrations is useful to evaluate the heavy metal burden but their mobility depends strongly on their specific chemical forms or ways of binding. However, the determination of specific chemical species or binding forms is as a rule very complex and often hardly possible. For this reason, sequential extraction procedures are commonly applied because they provide information about the fractionation of metals in the different lattices of the solid sample which is a good compromise to give information on environmental contamination risk (MARGUí et al., 2004).

For manganese determination highly sensitive methods are required. Various techniques have been used for the determination of trace manganese in biological and environmental samples, such as spectrophotometry and atomic absorption spectrometry. However the electronalytical techniques such as stripping analysis, which incorporate a preconcentration step, e.g. stripping voltammetry and stripping 
chronopotentiometry are the most used in trace metal determination in complex samples. These techniques have been shown to be suitable, versatile and rapid for multicomponent analysis, having good selectivity and adequate sensitivity (TOWN and LEEUWEN, 2001; FILIPE et al., 2003).

\section{Materials and methods}

\subsection{Samples}

Soils and sediments analyzed in this study were collected - from regions with high concentrations of anthropogenic and/or geogenic manganese - at five sampling sites:

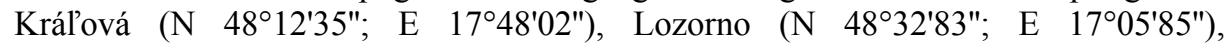
Kišovce (N 4901'18"; E 20³7'95"), Primovce (N 4901'18"; E 20³7'95") and Hôrka (N 4901'18"; E 20³9'06"). Soil samples were taken from top layer (horizon A; $0-15 \mathrm{~cm})$ and subsurface substrate $(35-45 \mathrm{~cm})$. The samples were air-dried, homogenized, screened through a $0.3 \mathrm{~mm}$ sieve, and stored for subsequent analysis.

\subsection{Mineralization}

Soil and sediment samples $(0.25 \mathrm{~g})$ have been transferred into PTFE digestion vessels and digested with $2 \mathrm{ml}$ of conc. $\mathrm{HCl}$ and $5 \mathrm{ml}$ of conc. $\mathrm{HNO}_{3}$ in a microwave oven Multiwave MW 3000 (Anton Paar GmbH, Austria) according to the following working conditions: $210^{\circ} \mathrm{C} ; 30 \mathrm{~min} ; 40$ bars. The acid solution was diluted to $25 \mathrm{ml}$ and the metal content was determined by FAAS using the atomic absorption spectrometer Varian Spectraa-200 (Varian Inc., Australia).

\subsection{Sequential extraction procedure}

The sequential extractions have been performed using the modified Tessier's procedure on $1 \mathrm{~g}$ of soil and sediment samples. The relevant procedure is described in Table 1.

Table 1. Sequential extraction procedure.

\begin{tabular}{|c|c|}
\hline Extracted fraction & Procedure \\
\hline F1- Exchangeable & $\begin{array}{l}1.0 \text { g sample; } 8 \mathrm{ml} 1 \mathrm{M} \mathrm{MgCl} \mathrm{MH}_{2}(\mathrm{pH}=7), 1 \mathrm{~h} \text { agitation; room temperature, } \\
\text { centrifugation } 4000 \mathrm{RPM}, 5 \mathrm{~min} \text {; rinsing of solid residue with } 3 \mathrm{ml} \text { deionized } \\
\mathrm{H}_{2} \mathrm{O} \text {; centrifugation } 4000 \mathrm{RPM}, 5 \mathrm{~min}\end{array}$ \\
\hline $\begin{array}{l}\text { F2- Bound to } \\
\text { carbonates }\end{array}$ & $\begin{array}{l}\text { solid residue from step } 1 ; 8 \mathrm{ml} 1 \mathrm{M} \mathrm{NaOAc}(\mathrm{pH}=5), 5 \mathrm{~h} \text { agitation; room } \\
\text { temperature, centrifugation } 4000 \mathrm{RPM}, 5 \mathrm{~min} \text {; rinsing of solid residue with } 3 \\
\text { ml deionized } \mathrm{H}_{2} \mathrm{O} \text {; centrifugation } 4000 \mathrm{RPM}, 5 \mathrm{~min}\end{array}$ \\
\hline $\begin{array}{l}\text { F3- Bound to Fe-Mn } \\
\text { oxides/Reducible }\end{array}$ & $\begin{array}{l}\text { solid residue from step } 2 ; 8 \mathrm{ml} 0.1 \mathrm{M} \mathrm{NH}_{2} \mathrm{OH} . \mathrm{HCl}(\mathrm{pH}=2), 16 \mathrm{~h} \text { agitation; room } \\
\text { temperature, centrifugation } 4000 \mathrm{RPM}, 5 \mathrm{~min} \text {; rinsing of solid residue with } 3 \\
\text { ml deionized } \mathrm{H}_{2} \mathrm{O} \text {; centrifugation } 4000 \mathrm{RPM}, 5 \mathrm{~min}\end{array}$ \\
\hline F4- Oxidisable & $\begin{array}{l}\text { solid residue from step } 2 ; 8 \mathrm{ml} 30 \% \mathrm{H}_{2} \mathrm{O}_{2}, 5 \mathrm{~h} \text { agitation; room temperature, } \\
\text { centrifugation } 4000 \mathrm{RPM}, 5 \mathrm{~min} \text {; rinsing of solid residue with } 3 \mathrm{ml} \text { deionized } \\
\mathrm{H}_{2} \mathrm{O} \text {; centrifugation } 4000 \mathrm{RPM}, 5 \mathrm{~min}\end{array}$ \\
\hline
\end{tabular}




\subsection{Galvanostatic stripping chronopotentiometry (SCP)}

The amount of $\mathrm{Mn}$ in obtained fractions after evaporation and dissolving in electrolyte has been determined by galvanostatic stripping chronopotentiometry using the flow-through system EcaFlow model GLP 150 (Istran Ltd., Slovakia).

For the determination, stripping chronopotentiometry on a macroporous electrode has been applied. At suitable positive potential $\mathrm{Mn}$ (II) is deposited from a slightly acidic solution on the electrode surface as a hydrate oxide:

$$
\mathrm{Mn}\left(\mathrm{H}_{2} \mathrm{O}\right)_{x}^{2+} \rightarrow \mathrm{Mn}\left(\mathrm{H}_{2} \mathrm{O}\right)_{x-3}(\mathrm{OH})_{3}+3 \mathrm{H}^{+}+e^{-}
$$

In the next step the deposit is stripped applying a constant negative current. During this step the signal (chronopotentiogram) is recorded and the concentration of $\mathrm{Mn}$ in the sample is evaluated.

The compact flow-through electrochemical cell EcaCell 104, $\mathrm{Ag} / \mathrm{AgCl}$ reference electrode and carbon porous working electrode E-104 has been used. Basic (carrier) electrolyt solution of $0.1 \mathrm{~mol} \mathrm{dm}^{-3} \mathrm{Na}_{2} \mathrm{SO}_{4}+0.01 \mathrm{~mol} \mathrm{dm} \mathrm{NaH}_{2} \mathrm{PO}_{4}$ and reagent solution of $0.1 \mathrm{~mol} \mathrm{dm}^{-3} \mathrm{HCl}$ has been used. Standard solutions $50 \mu \mathrm{g} \mathrm{dm}{ }^{-3}, 100 \mu \mathrm{g}$ $\mathrm{dm}^{-3}$ and $200 \mu \mathrm{g} \mathrm{dm}^{-3} \mathrm{Mn}$ (II) were prepared from certified reference material (Merck). Deionised water (conductivity of $0.054 \mu \mathrm{S} \mathrm{cm}^{-1}$ ) has been used for all solutions. In all experiments analytical grade reagents were used. Table 2 shows the applied experimental parameters for Mn determination using SCP.

Table 2. Experimental conditions for the determination of Mn (www.istran.sk).

\begin{tabular}{lc}
\hline Deposition potential & $1100 \mathrm{mV}$ \\
Deposition time & $60 \mathrm{~s}$ \\
Initial potential & $1100 \mathrm{mV}$ \\
Final potential & $500 \mathrm{mV}$ \\
Dissolution current & $-25 \mu \mathrm{A}$ \\
Time of stabilization & $10 \mathrm{~s}$ \\
Max. time of stripping & $120 \mathrm{~s}$ \\
Regeneration potential & $400 \mathrm{mV}$ \\
Time of regeneration & $10 \mathrm{~s}$ \\
Volume of sample & $1 \mathrm{ml}$ \\
,Standby“ potential & $650 \mathrm{mV}$ \\
\hline
\end{tabular}

\section{Results and discussion}

The total Mn concentrations and the manganese fractions obtained by the chosen sequential extraction procedures are shown in Tables 3-5.

Samples from Král'ová contain anthropogenic manganese markedly derived from waste dump of a former nickel smelter in Sered'. Manganese in sediments has been found only in carbonate fraction. This is caused evidently by higher $\mathrm{pH}$ values of the water reaching 8.2.

Manganese in soil samples from the same site has been bound to Fe-Mn oxides in higher proportion, while significant differences of its abundance in different soil horizons have not been observed. 
The total Mn concentrations of investigated soil samples show similar values as well. Our results show for manganese concentrations in soils - in comparison with the ones in sediments - higher values. We assume that for soils floods may act as a not negligible source of $\mathrm{Mn}$. In the same time by lower $\mathrm{pH}$ values caused by acid rains the soluble Mn species reach the deeper soil horizons.

Table 3. Concentrations of $\mathrm{Mn}$ in samples of stream sediments after modified Tessier's extraction procedure.

\begin{tabular}{|c|c|c|c|c|c|}
\hline \multirow{2}{*}{ Sample } & \multicolumn{4}{|c|}{$\begin{array}{l}\text { Concentration of } \mathrm{Mn} \pm \text { SD in fractions } \\
{\left[\mathrm{mg} \mathrm{kg}^{-1}\right]}\end{array}$} & \multirow{2}{*}{$\begin{array}{c}\text { Total } \\
\text { concentration } \\
\text { of } \mathrm{Mn} \pm \mathrm{SD} \\
{\left[\mathrm{mg} \mathrm{kg}^{-1}\right]}\end{array}$} \\
\hline & F1 & F2 & F3 & F4 & \\
\hline Král'ová & - & $141.4 \pm 2.9$ & - & - & $278.6 \pm 3.9$ \\
\hline Lozorno & - & $48.2 \pm 3.6$ & $645.8 \pm 22.1$ & - & $779.9 \pm 10.9$ \\
\hline Hôrka & - & $594.9 \pm 2.1$ & $2586.8 \pm 56.1$ & $219.5 \pm 0.2$ & $6243.6 \pm 56.2$ \\
\hline Kišovce & - & $209.9 \pm 12.8$ & $50.3 \pm 6.7$ & $2.4 \pm 0.8$ & $617.3 \pm 13.6$ \\
\hline Primovce & - & $969.1 \pm 5.2$ & $516.6 \pm 11.3$ & $45.2 \pm 0.4$ & $3219.8 \pm 61.2$ \\
\hline
\end{tabular}

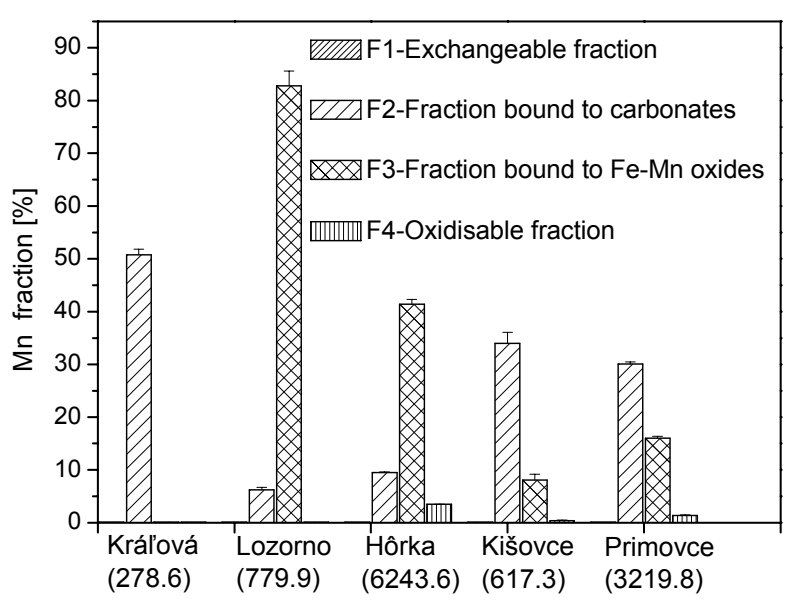

Fig. 1. Percentual abundance of Mn in particular fractions using modified Tessier's extraction procedure in sediment samples (data under the graph represent total manganese concentrations $\left[\mathrm{mg} \mathrm{kg}^{-1}\right]$ determined by FAAS).

Table 4. Concentrations of Mn in soil samples taken from horizon A after modified Tessier's extraction procedure.

\begin{tabular}{|c|c|c|c|c|c|}
\hline \multirow[t]{2}{*}{ Sample } & \multicolumn{4}{|c|}{$\begin{array}{l}\text { Concentration of } \mathrm{Mn} \pm \text { SD in fractions } \\
\qquad\left[\mathrm{mg} \mathrm{kg}^{-1}\right]\end{array}$} & \multirow{2}{*}{$\begin{array}{c}\text { Total concentration of } \\
\text { Mn } \pm \text { SD } \\
{\left[\mathrm{mg} \mathrm{kg}^{-1}\right]}\end{array}$} \\
\hline & F1 & F2 & F3 & F4 & \\
\hline Král'ová & - & $101.2 \pm 4.0$ & $145.9 \pm 1.8$ & $14.7 \pm 0.6$ & $733.2 \pm 10.9$ \\
\hline Lozorno & - & $27.4 \pm 0.9$ & $471.6 \pm 3.3$ & - & $590.1 \pm 7.08$ \\
\hline Kišovce & - & $145.4 \pm 9.2$ & $309.6 \pm 5.4$ & $85.7 \pm 27.9$ & $1339.7 \pm 26.8$ \\
\hline Primovce & - & $498.9 \pm 6.4$ & $620.9 \pm 23.9$ & $167.6 \pm 4.1$ & $2426.6 \pm 16.9$ \\
\hline
\end{tabular}




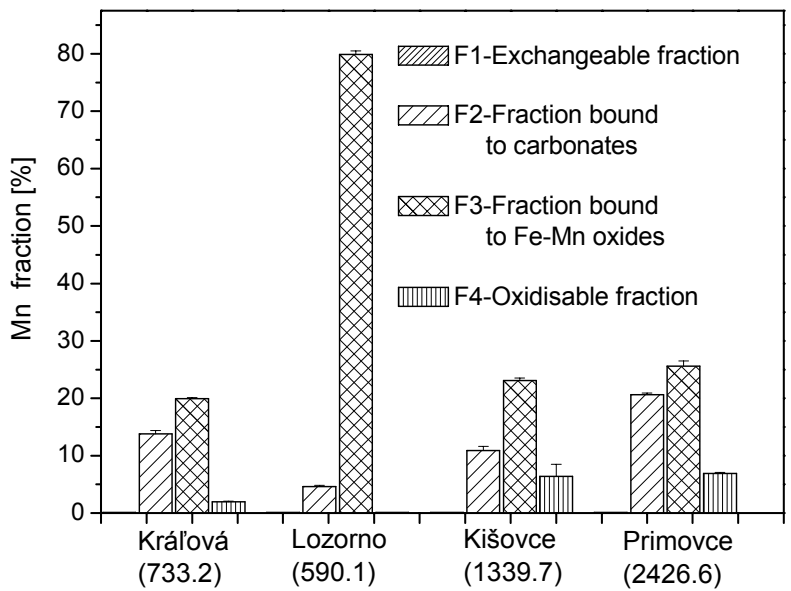

Fig. 2. Percentual abundance of Mn in particular fractions of the modified Tessier's extraction procedure in soil samples taken from horizon A (data under the graph represent total manganese concentrations [ $\mathrm{mg} \mathrm{kg}^{-1}$ ] determined by FAAS).

Table 5. Concentrations of $\mathrm{Mn}$ in soil samples taken from subsurface substrate after modified Tessier's extraction procedure.

\begin{tabular}{|c|c|c|c|c|c|}
\hline \multirow[t]{2}{*}{ Sample } & \multicolumn{4}{|c|}{$\begin{array}{c}\text { Concentration of } \mathrm{Mn} \pm \text { SD in fractions } \\
{\left[\mathrm{mg} \mathrm{kg}^{-1}\right]}\end{array}$} & \multirow{2}{*}{$\begin{array}{c}\text { Total concentration of } \\
\mathrm{Mn} \pm \mathrm{SD} \\
{\left[\mathrm{mg} \mathrm{kg}{ }^{-1}\right]}\end{array}$} \\
\hline & F1 & $\mathrm{F} 2$ & F3 & F4 & \\
\hline Král'ová & - & $79.9 \pm 5.4$ & $198.3 \pm 6.1$ & $32.3 \pm 0.6$ & $757.7 \pm 12.1$ \\
\hline Lozorno & - & $4.5 \pm 0.4$ & $343.2 \pm 5.3$ & - & $446.6 \pm 15.2$ \\
\hline Kišovce & - & $81.8 \pm 6.6$ & $65.5 \pm 1.2$ & $8.9 \pm 0.5$ & $488.1 \pm 8.3$ \\
\hline Primovce & - & $298.9 \pm 32.3$ & $952.8 \pm 126.6$ & $248.3 \pm 15.2$ & $2620.8 \pm 28.8$ \\
\hline
\end{tabular}

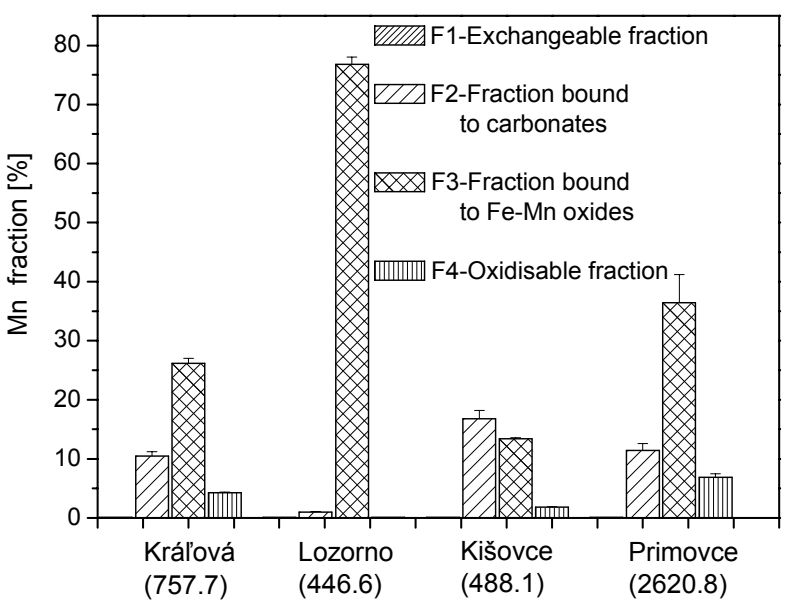

Fig. 3. Percentual abundance of Mn in particular fractions of the modified Tessier's extraction procedure in soil samples taken from subsurface substrate (data under the graph represent total manganese concentrations $\left[\mathrm{mg} \mathrm{kg}^{-1}\right]$ determined by FAAS). 
Acidic soils are typical for Zahorie region. This is evidently caused by chemically inactive soil constituents. Both, iron and manganese as well, are at oxidizing conditions in higher oxidation states and so they are present in precipitated chemical forms. In such conditions major proportions of iron and manganese in sediments as well as in investigated soil horizons are bound to Fe and Mn oxides.

The highest contents of total manganese have been measured in samples taken from Hôrka, Kišovce and Primovce. This region is known as one with high geogenic manganese concentrations. At lower $\mathrm{pH}$ values the carbonate system consists of hydrogen carbonates predominantly and manganese is in such conditions soluble.

According to our observation sediments near Hôrka contain extremely high manganese concentrations. This fact is avowedly caused by former mining activity. We found that manganese is in this region predominantly bound to $\mathrm{Mn}-\mathrm{Fe}$ oxides caused apparently by oxidation of manganese originated from mining activity.

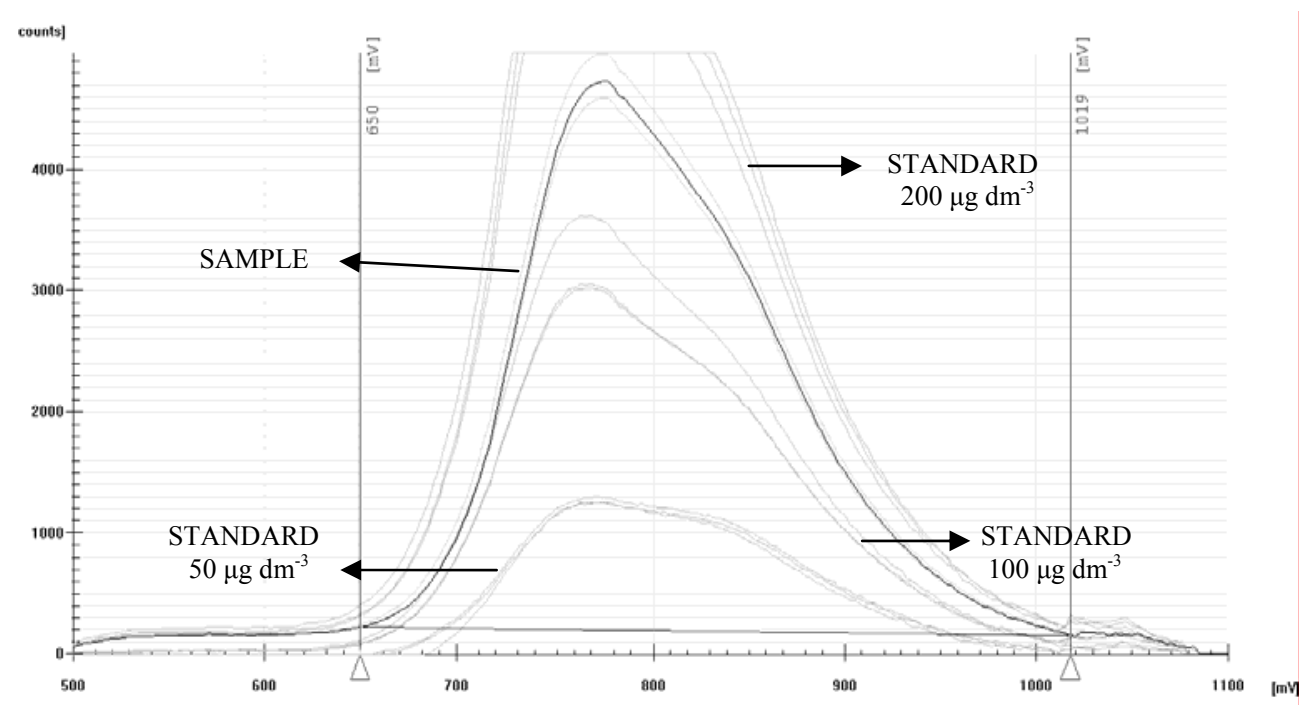

Fig. 4. Typical chronopotentiograms obtained by manganese determination using SCP.

\section{Conclusions}

Results of fractionation experiments prove that the type of manganese coupling to the sediment- and soil matrix is strongly affected by factors connected to geological bedrock as well as to relevant $\mathrm{pH}$ values. In regions with low $\mathrm{pH}$ values the carbonate system consists mostly from hydrogen carbonates and at such conditions manganese is soluble. For this reason manganese in sediments from Lozorno and Hôrka is present in fraction bound to Fe-Mn oxides, namely $80 \%$ and $42 \%$ respectively.

In regions with higher $\mathrm{pH}$ values the solubility of carbonates is low. Manganese in sediment from Králová is bound to carbonates, namely $>50 \%$. 


\section{References}

ANJOS, A.P, PONCE, L.C., CADORE, S., BACCAN, N.: Determination of manganese by flame atomic absorption spectrometry after its adsorption onto naphthalene modified with 1-(2-pyridylazo)-2-naphtol (PAN). Talanta, 71, 2007, 1252-1256.

BANKS, C.G., KRUUSMA, J., MOORE, R.R., TOMČÍK, P., PETERS, J., DAVIS, J., LOVRIĆ, Š.K., COMPTON, R.G.: Manganese detection in marine sediments: anodic vs. cathodic stripping voltammetry. Talanta, 65, 2005, 423-429.

BEINROHR, E.: Determination of $\mathrm{Mn}$ in clean as well as turbid water samples, Application list No.74. ISTRAN Ltd., Slovakia. http://www.istran.sk/en/ Download/Start-download/English/Application-lists/33-Application-listNo.74.html

FILIPE, O.M.S, BRETT, C.M.A.: Cathodic stripping voltammetry of trace Mn(II) at carbon film electrodes. Talanta, 61, 2003, 643-650.

KHOO, S.B., SOH, M.K., CAI, Q., KHAN, M.R., GUO, S.X.: Differential pulse cathodic stripping voltammetric determination of manganese(II) and manganese(VII) at the 1-(2-pyridylazo)-2-naphtol-modified carbon paste electrode. Electroanalysis, 9, 1997, 45-51.

LEMOS, V.A., BALIZA, P.X., CARVALHO, A.L., OLIVEIRA, R.V., TEIXEIRA, L.S.G., BEZERRA, M.A.: Development of a new sequential injection in-line cloud point extraction system for flame atomic absorption spectrometric determination of manganese in food samples. Talanta, 77, 2008, 388-393.

MARGUÍ, E., SALVADÓ, V., QUERALT, I., HIDALGO, M.: Comparison of threestage sequential extraction and toxicity characteristic leaching tests to evaluate metal mobility in mining wastes. Anal. Chim. Acta, 524, 2004, 151-159.

PEARSON, G.P, GREENWAY, G.M.: Recent developments in manganese speciation. Trends Anal. Chem., 24, 2005, 803-809.

TOWN, R.M., LEEUWEN, H.P.: Fundamental features of metal ion determination by stripping chronopotentiometry. J. Electroanal. Chem., 509, 2001, 58-65. 